\title{
High frequency of MLH1 promoter methylation mediated by gender and age in colorectal tumors from Mexican patients
}

José M. Moreno-Ortiz', Josselyn Jiménez-García1, Melva Gutiérrez-Angulo², Ma. de la Luz Ayala-Madrigal', Anahí González-Mercado', Christian O. González-Villaseñor', Beatriz A. Flores-López', Carlos Alvizo-Rodríguez', Jesús A. Hernández-Sandoval', Martha A. Fernández-Galindo, Víctor Maciel-Gutiérrez ${ }^{3}$, Helen Ramírez-Plascencia ${ }^{1}$ and Ruth Ramírez-Ramírez ${ }^{4}$

${ }^{1}$ Department of Molecular Biology and Genomics, Dr. Enrique Corona Rivera Human Genetics Institute, Health Sciences University Center, Universidad de Guadalajara; ${ }^{2}$ Department of Health Sciences, Los Altos University Center, Universidad de Guadalajara; ${ }^{3}$ Department of Colon and Rectum, Hospital Civil Dr. Juan I. Menchaca; ${ }^{4}$ Department of Cellular and Molecular Biology, University Center for Biological and Farming Sciences, Universidad de Guadalajara. Jalisco, Mexico

\begin{abstract}
Introduction: Several genes determine the development of colorectal cancer (CRC), such as MLH1, which encodes a protein that participates in DNA repair. MLH1 hypermethylation has been associated with gene silencing. Objective: To analyze the methylation of five regions of MLH1 CDG island in colorectal tumors from Mexican patients. Materials and methods: One hundred and one tumor tissue samples were obtained from Mexican patients with CRC who provided informed consent. DNA was subjected to bisulfite conversion. Methylation of all five regions of the CPG island was evaluated using methylation-specific PCR. Results: The frequency of methylation in Mexican patients with CRC was $25 \%$. Regions $A$ and $B$ methylation was the main observed pattern (60\%). Female patients showed a higher frequency of methylation (71\%; OR: 3.085; Cl: 1.85-8.03; $p=0.02)$, and out of total methylated samples, $80 \%$ corresponded to individuals older than 45 years $(p<0.05)$. Conclusion: We calculated a methylation frequency for the MLH1 gene of $25 \%$ in Mexican patients with CRC, with this being the first report for this population. Female patients and patients older than 45 years showed a higher frequency of methylation.
\end{abstract}

KEY WORDS: Colorectal cancer. Methylation Mexican population. MLH1.

\section{Elevada frecuencia de metilación del promotor de MLH1 mediada por sexo y edad en tumores colorrectales de pacientes mexicanos}

\section{Resumen}

Introducción: Varios genes determinan el desarrollo de cáncer colorrectal (CCR), como MLH1, el cual codifica una proteína que participa en la reparación del ADN. La hipermetilación de MLH1 ha sido asociado con silenciamiento génico. Objetivo: Analizar la metilación de cinco regiones de la isla CpG de MLH1 en tumores colorrectales de pacientes mexicanos. Materiales y métodos: Se obtuvieron 101 muestras de tejido tumoral de pacientes mexicanos con CCR, quienes proporcionaron su consentimiento informado. El ADN fue sometido a conversión por bisulfito. La metilación de las cinco regiones de la isla CpG fue evaluada utilizando PCR específica para metilación. Resultados: La frecuencia de metilación en pacientes mexicanos con CCR fue del 25\%. La metilación de las regiones A y B fue el principal patrón observado (60\%). Las pacientes de sexo femenino mostraron una mayor frecuencia de metilación (71\%) (odds ratio: 3.085; intervalo de confianza; 1.85-8.03;

Correspondence:

*Ruth Ramírez-Ramírez

E-mail: ruth.ramirez@academicos.udg.mx
Gac Med Mex. 2021;157:618-623

Contents available at PubMed

www.gacetamedicademexico.com

0016-3813/@ 2021 Academia Nacional de Medicina de México, A.C.. Published by Permanyer. This is an open access article under the CC BY-NC-ND license (http://creativecommons.org/licenses/by-nc-nd/4.0/). 
$p=0.02) ; y$ del total de muestras metiladas, el 80\% fueron individuos mayores de 45 años $(p<0.05)$. Conclusión: Calculamos una frecuencia de metilación para el gen MLH1 del 25\% en pacientes mexicanos con CCR, siendo el primer reporte para esta población. Pacientes de sexo femenino y pacientes mayores de 45 años mostraron una mayor frecuencia de metilación.

PALABRAS CLAVE: Cáncer colorrectal. Metilación. Población mexicana. MLH1.

\section{Introduction}

Colorectal cancer (CRC) is the third leading cause of tumor-related death in the world ${ }^{1,2}$. Approximately $45 \%$ of cases occur in developing regions ${ }^{1,3}$. CRC usually occurs in adults with an average age of 67 years ${ }^{4}$. In Mexico, in terms of incidence and mortality, CRC is the third most common cancer in both genders'.

CRC is a neoplasm in which epigenetic processes such as $\mathrm{CpG}$ islands hypermethylation occur, which leads to gene inactivation and normal cell growth and function alteration ${ }^{5}$. MLH1 hypermethylation has been described as a prognostic marker for this neoplasm ${ }^{6}$. The MLH1 protein is part of a protein complex that participates in the mismatch repair system ${ }^{7-9}$. The MLH1 gene is located at 3p22.2 and contains 19 exons $^{10}$. Its expression is regulated by its promoter, and although it lacks a TATA box, it contains the CCAAT sequence that is necessary for transcription factors binding ${ }^{11}$. MLH1 has a 1128-bp CpG island, where $93 \mathrm{CpG}$ sites are found (chr3: 37034229-37035356) ${ }^{12}$. In sporadic CRC, MLH1 is methylated at $10-15 \%$. Four regions of the CpG island have been studied in colorectal carcinoma cell lines: A (-711 to -577$)$, B (-522 to -266$),$ C (-248 to -178$)$ and $D(-109$ to +5$)$, with hypermethylation being correlated with $M L H 1$ gene expression inhibition ${ }^{13,14}$. On the other hand, in the Japanese population, analysis of five regions has been reported: A (-755 to -574$), B(-597$ to -393$), C(-420$ to -188$), D(-286$ to -53$)$ and $E(-73$ to $+86)$, with total and partial methylation being correlated with clinical-pathological characteristics, protein expression and microsatellite instability ${ }^{15}$.

There are no specific MLH1 methylation reports in Mexican patients with CRC. Owing to this, the purpose of the present study was to analyze the methylation frequency of five regions of the MLH1 CpG island in Mexican patients with CRC.

\section{Materials and methods}

\section{Samples}

One hundred and one tumor tissue samples were collected from Mexican patients clinically and histopathologically diagnosed with $\mathrm{CRC}$ at Dr. Juan I. Menchaca Civil Hospital (Guadalajara, Jalisco, Mexico). Tissue samples were obtained at the conclusion of surgery. All patients signed an informed consent based on the Declaration of Helsinki. The study was approved by the local bioethics committee (Cl-01417).

\section{DNA extraction and quantification}

DNA was extracted from tumor tissues (High Pure PCR Template Preparation kit [product no.: 11796828001], Roche Diagnostic GmbH, Mannheim, Germany). Subsequently, the DNA was quantified by spectrophotometry. Samples were stored at $-20{ }^{\circ} \mathrm{C}$ until their use.

\section{DNA conversion by bisulfite}

A DNA concentration of $100 \mu \mathrm{g} / \mathrm{mL}(18 \mu \mathrm{L})$ was used and subsequently treated with the EZ DNA Methylation-Gold kit (product no.: D5006; ZYMO Research, USA). DNA from the HCT116 DKO cell line (product no.: D5014; ZYMO Research) was used as control during the conversion analysis and methylation-specific polymerase chain reaction (MS-PCR).

\section{Methylation-specific polymerase chain reaction}

The $\mathrm{CpG}$ island was divided into five regions for methylation analysis: A (-539 to -677$), \mathrm{B}(-418$ to -264$)$, $C(-162$ to -62$), D(+82$ to +260$)$ and $E(+234$ to +415$)$. MS-PCR was carried out for all regions using converted DNA. The primers used for methylated and unmethylated DNA are described in table 1. MS-PCR was carried out for all regions at 30 cycles, in a volume of $12 \mu \mathrm{L}$, which contained $100 \mathrm{ng} / \mu \mathrm{L}$ DNA, $1 \times$ buffer $\left(500 \mathrm{mM} \mathrm{KCl}, 100 \mathrm{mM}\right.$ Tris- $\mathrm{HCl}$ and $0.1 \%$ Triton $^{\mathrm{TM}}$ X-100), $1.5 \mathrm{mM} \mathrm{MgCl}_{2}, 2 \mathrm{mM}$ dNTP, $10 \mathrm{pM}$ of each primer and $2 \mathrm{U}$ of Platinum Taq DNA polymerase. Initial denaturation was carried out at $95^{\circ} \mathrm{C}$ for $5 \mathrm{~min}$, followed by $94{ }^{\circ} \mathrm{C}$ for $45 \mathrm{~s}$, alignment at $57^{\circ} \mathrm{C}$ for $45 \mathrm{~s}$ and elongation at $72^{\circ} \mathrm{C}$ for $1 \mathrm{~min}$. The PCR products 
Table 1. MLH1 gene primers used for A, B, C, D, and E regions methylated and unmethylated DNA amplification

\begin{tabular}{|c|c|c|c|}
\hline CpG island regions & $\mathrm{M} / \mathrm{U}$ & Primers & Fragment size (bp) \\
\hline \multirow[t]{4}{*}{ A } & \multirow[t]{2}{*}{ M } & F5'-CGGTAGAGTTCGAGGTTTGTAC-3' & \multirow[t]{2}{*}{134} \\
\hline & & R5'-CACGAATACTACGAACGATATATAACG-3' & \\
\hline & \multirow[t]{2}{*}{$U$} & F5' GTGGTAGAGTTTGAGGTTTGTATGA-3' & \multirow[t]{2}{*}{138} \\
\hline & & R5'-AAACACAAATACTACAAACAATATATAACA-3' & \\
\hline \multirow[t]{4}{*}{ B } & \multirow[t]{2}{*}{ M } & F5'- GTCGGAAAATTAGAGTTTCGTC-3' & \multirow[t]{2}{*}{151} \\
\hline & & R5'-GCAAAACGAAAAAAATACTTAACG-3' & \\
\hline & \multirow[t]{2}{*}{ U } & F5'- GGTTGGAAAATTAGAGTTTTGTTGA-3' & \multirow[t]{2}{*}{154} \\
\hline & & R5'-ACAAAACAAAAAAAATACTTAACACA-3' & \\
\hline \multirow[t]{4}{*}{ C } & \multirow[t]{2}{*}{ M } & F5'-GATAGCGATTTTTAACGC-3' & \multirow[t]{2}{*}{93} \\
\hline & & R5'-TCTATAAATTACTAAATCTCTTCG-3' & \\
\hline & \multirow[t]{2}{*}{ U } & F5'-AGAGTGGATAGTGATTTTTAATGT-3' & \multirow[t]{2}{*}{100} \\
\hline & & R5'-ACTCTATAAATTACTAAATCTCTTCA-3' & \\
\hline \multirow[t]{4}{*}{ D } & \multirow[t]{2}{*}{ M } & F5'-GTTTTTTTGGCGTTAAAATGTC-3' & \multirow[t]{2}{*}{166} \\
\hline & & R5'- CCTTAAATAAACCCGACTCGAC-3' & \\
\hline & \multirow[t]{2}{*}{ U } & F5' -TTGGTTTTTTTTGGTGTTAAAATGTT-3' & \multirow[t]{2}{*}{172} \\
\hline & & R5'-AACCCTTAAATAAACCCAACTCAAC-3' & \\
\hline \multirow[t]{4}{*}{ E } & \multirow[t]{2}{*}{ M } & F5'-GAGTCGGGTTTATTTAAGGGTTAC-3' & \multirow[t]{2}{*}{177} \\
\hline & & R5'-GATAAAAAAACACACGATCTACGAA-3' & \\
\hline & \multirow[t]{2}{*}{ U } & F5'-AGTTGGGTTTATTTAAGGGTTATGA-3' & \multirow[t]{2}{*}{176} \\
\hline & & R5'- AATAAAAAAACACACAATCTACAAA-3' & \\
\hline
\end{tabular}

M: methylated; U: unmethylated; bp: base pairs; F: forward; R: reverse.

were visualized on polyacrylamide gels stained with $6 \%$ silver nitrate.

\section{Statistical analysis}

SPSS v25 software (SPSS, Inc., Chicago, IL, USA) was used for statistical analysis. Fisher's exact test, chi-square test and odds ratios $(\mathrm{OR})$, were used for methylation analysis. $p$-values $<0.05$ were regarded as significant.

\section{Results}

One hundred and one tumor tissue samples from Mexican patients with CRC were analyzed; average age was 59 years. Analyzed characteristics included gender (52\% males), physical activity (53\%), type II diabetes mellitus (21\%), consumption of tobacco, alcohol, red meat and fruits and vegetables (42, 49, 81 and $75 \%$, respectively), metastasis (42\%), presence of polyps (17\%), relapses (4\%) and tumor location (colon, 60\%).

\section{Methylation analysis}

The frequency of $M L H 1$ methylation in Mexican patients with CRC was $25 \%$. However, among total methylated samples, methylation frequency was $60 \%$ in regions $A$ and $B$ (Table 2).

Methylation frequency was compared according to clinical-pathological and lifestyle characteristics, with significant differences being found for gender and age $(p<0.05)$ (Table 3$)$. Of total methylated samples, $68 \%$ corresponded to female patients. In addition, two age ranges were established ( $<45$ and $>45$ years of age); out of total methylated samples, $80 \%$ corresponded to patients older than 45 years. 
Table 2. Methylation analysis of $M L H 1$ gene CpG island regions of tumor tissue from patients with colorectal cancer

\begin{tabular}{l|c|}
\hline \multirow{2}{*}{ Methylated region } & Total methylated samples \\
\cline { 2 - 2 } & $n=25(\%)$ \\
\hline A & $15(60)$ \\
\hline C & $15(60)$ \\
\hline D & $7(28)$ \\
E & $8(32)$ \\
\hline
\end{tabular}

The frequency of methylation (25\%) was compared with the frequencies reported in other populations, with significant differences being found (Table 4).

\section{Discussion}

\section{Methylation analysis}

In the present study, five $\mathrm{CpG}$ island regions were analyzed. It should be noted that regions $D$ and $E$ had not been previously analyzed by other authors (Table 5). The five analyzed regions cover a total of $63 \mathrm{CpG}$ island sites.

Previous studies analyzed four regions rich in $\mathrm{CpG}$ sites by means of sequencing; however, cell lines were used, covering $43 \mathrm{CpG}$ sites. In particular, these studies showed a correlation between $C$ or $D$ region methylation and gene expression inhibition due to the presence of the CCAAT sequence; methylation of this sequence inhibits transcription core binding factor (CBF) binding. According to these studies, hypermethylation in $M L H 1$ promoter $C$ and $D$ regions causes inactivation and deficiency of the protei ${ }^{13,14}$. In our study, $28 \%$ of the samples were found to be methylated at $C$ region and $32 \%$ were methylated at $D$ region. These regions are found around the transcription start site, but always have a lower methylation frequency than the other regions ${ }^{22}$. For example, regions $A$ and $B$ are the most commonly methylated ${ }^{23}$; however, the functional effect of these regions has not been directly described. In this regard, in the present study, a higher frequency of methylation was observed in regions $A$ and $B(60 \%)$. Another report revealed that region $A$ may be the first site to be methylated during progression to a methylation state ${ }^{15}$. These regions $(A, B)$ are the furthest from the transcription start site. On the other hand, all methylated tumors in region $C$ showed methylation in regions $A$ and $B$, which was a constant in our study, but the authors showed cases of methylation only in regions $A$ and $B$, and not in region $\mathrm{C}^{13}$.

Methylation frequency was $25 \%$ for MLH1. DNA methylation is known to be able to affect transcription factor binding sites, regulatory elements and chromatin conformation, which results in multiple levels of expression control ${ }^{24}$. This frequency is higher than that proposed by other authors, who refer a MLH1 methylation frequency of between 10 and $15 \%$ in cases of sporadic $\mathrm{CRC}^{5}$. Even our percentage was also higher than that reported in other populations $s^{7,16-21}$.

\section{Gender-mediated methylation}

CRC is a complex disease that involves several factors ${ }^{25-28}$. In the present study, the correlation of some of these factors with methylation was examined. However, there were only significant differences with regard to gender and age. Specifically, MLH1 methylation has been associated with clinical-pathological variables, including the female gender ${ }^{29}$. In this study, the frequency of methylation was higher in women (OR: 3.085; confidence interval $[\mathrm{Cl}]$ : 1.858.03; $p=0.02$ ); these findings are similar to those reported in different studies ${ }^{16,18}$. A report that included 210 samples from patients with $\mathrm{CRC}$ revealed higher methylation in women $(p=0.007)$. In addition, the presence of the MLH1 c.-93G>A variant (rs1800734) was proposed to lead to a higher risk of methylation in women ${ }^{21}$. Interestingly, in this work, those women who had some methylated region had the presence of overweight or obesity in common, as well as that at some stage of their life they had consumed tobacco and alcohol. In this regard, there is sufficient evidence of the influence of these factors on DNA methylation ${ }^{30-32}$.

\section{Age-mediated methylation}

The methylation frequency analysis by age range revealed higher rates of methylation in individuals older than 45 years $(80 \%)$. However, the effect of age on methylation status remains unclear. The only study involving $\mathrm{MLH} 1$ that associated aging with aberrant methylation showed that methylation increased with age (frequency per 10 years of age $=2.1 \% ; p<0.001)^{33}$. Furthermore, MLH1 methylation in tumor samples was found to occur more frequently in those from subjects 
Table 3. Comparison of $\mathbf{M L H} 1$ gene CpG island regions methylation frequency by gender

\begin{tabular}{|c|c|c|c|c|c|c|}
\hline \multirow[t]{3}{*}{ Regiones } & \multicolumn{4}{|c|}{ CRC patients $(n=101)$} & \multirow[t]{3}{*}{ p } & \multirow[t]{3}{*}{ OR (CI) } \\
\hline & \multicolumn{2}{|c|}{ Male gender $(n=53)$} & \multicolumn{2}{|c|}{ Female gender $(n=48)$} & & \\
\hline & M & $\mathbf{U}$ & M & U & & \\
\hline Any region* & $8(15.1 \%)$ & $45(84.9 \%)$ & $17(35.4 \%)$ & $31(64.6 \%)$ & 0.018 & $3.085(1.9-8.0)$ \\
\hline A & $3(5.7 \%)$ & $50(94.3 \%)$ & $12(25.0 \%)$ & $36(75.0 \%)$ & 0.01 & $5.556(1.5-21.1)$ \\
\hline B & $4(7.5 \%)$ & $49(92.5 \%)$ & $11(22.9 \%)$ & $37(77.1 \%)$ & 0.048 & $3.642(1.1-12.4)$ \\
\hline$A+B$ & $2(3.8 \%)$ & $51(96.2 \%)$ & $9(18.8 \%)$ & 39 (81.3\%) & 0.023 & $5.885(1.2-28.8)$ \\
\hline
\end{tabular}

*Samples methylated on any analyzed region (A, B, C, D, E).

CRC: colorectal cancer; M: methylated; OR: odds ratio; Cl: confidence interval; U: unmethylated.

Table 4. MLH1 gene methylation frequency between different populations of patients with colorectal cancer

\begin{tabular}{|c|c|c|c|c|c|}
\hline Population & n & Analyzed tumor tissue & M (\%) & p & Reference \\
\hline Australian & 946 & Fresh tissue & 10.1 & 0.0001 & Wong et al., $2011^{16}$ \\
\hline Japanese & 104 & Fresh tissue & 9.6 & 0.0039 & Hokazono et al., $2014^{17}$ \\
\hline Japanese & 210 & Fresh tissue & 28.5 & 0.4935 & Miyakura et al., $2014^{18}$ \\
\hline Chinese & 301 & Fresh tissue & 14.6 & 0.0188 & Wang et al., $2014^{19}$ \\
\hline Spanish & 326 & Fresh tissue & 5.2 & 0.0001 & Veganzones et al., $2015^{20}$ \\
\hline Korean & 132 & Fresh tissue & 6 & 0.0001 & Lee et al., $2019^{21}$ \\
\hline Slovakian & 300 & Paraffin-embedded tissue & 7.6 & 0.0001 & Kašubová et al., 201977 \\
\hline Mexican & 101 & Fresh tissue & 25 & - & Present study \\
\hline
\end{tabular}

Tale 5. Comparison between different MLH1 gene CpG island regions reported by Deng et al. (2001), Miyakura et al. (2001 and 2014) and this study

\begin{tabular}{|l|c|c|c|}
\hline Region & $\begin{array}{c}\text { Deng et al., } \\
2001^{14}\end{array}$ & $\begin{array}{c}\text { Miyakura et al., 2001 } \\
\text { Miyakura et al., 2014 }\end{array}$ & This study \\
\hline A & -711 to -577 & -755 to -574 & -677 to -539 \\
\hline B & -552 to -266 & -597 to -393 & -418 to -264 \\
\hline C & -248 to -178 & -420 to -188 & -162 to -62 \\
\hline D & -109 to +5 & -286 to -53 & +82 to +260 \\
\hline E & & -73 to +86 & +234 to +415 \\
\hline
\end{tabular}

older than 50 years ${ }^{29}$. In our study, elevated levels of methylation were more common in women older than 45 years.

\section{Population methylation analysis}

The population analysis showed that the frequency of methylation in patients with CRC in the Mexican population was significantly different from those in other populations, including Australian, Japanese, Chinese, Spanish, Korean and Slovakian populations ${ }^{7,16-21}$. These differences are probably due to the variability in the number of samples used at each study, the different regions analyzed by each author, the lifestyle and characteristic genetic structure of Mexicans. However, in this study, no significant data were found when the association of methylation with aspects related to lifestyle was analyzed.

\section{Conclusion}

The present analysis showed an MLH1 methylation frequency of $25 \%$. This value is higher than that reported in other populations and constitutes the first report in Mexican patients with CRC. Analysis by regions revealed that regions $A$ and $B$ had a higher methylation frequency $(60 \%)$. Finally, $80 \%$ of methylated samples corresponded to patients older than 45 years, and high levels of methylation were found in female patients, which indicates a relevant role of both these factors in DNA methylation. 


\section{Acknowledgments}

The study was funded by PRODEP. Christian Octavio González-Villaseñor, Beatriz Armida López-Flores, Carlos Alvizo-Rodríguez, Jesús Arturo Hernández-Sandoval, Martha Alejandra Fernández Galindo and Helen Ramírez-Plascencia received a doctoral scholarship granted by CONACyT.

\section{Funding}

The study was funded by PRODEP
UDG-PTC-1456.

\section{Conflict of interests}

The authors declare that they have no conflicts of interest.

\section{Ethical disclosures}

Protection of human and animal subjects. The authors declare that the procedures that were followed adhered to the standards of the research ethics committee and to the World Medical Association code of ethics (Declaration of Helsinki).

Confidentiality of data. The authors declare that they have followed the protocols of their work center on the publication of patient data.

Right to privacy and informed consent. The authors have obtained written informed consent from the patients or subjects mentioned in the article. This document is in the possession of the corresponding author.

\section{References}

1. Bray F, Ferlay J, Soerjomataram I, Siegel RL, Torre LA, Jemal A. Global Cancer Statistics 2018: GLOBOCAN Estimates of Incidence and Mortality Worldwide for 36 Cancers in 185 Countries. CA Cancer J Clin. 2018;68:394-424.

2. Han S, Gao J, Zhou Q, Liu S, Wen S, Yang X. Role of intestinal flora in colorectal cancer from the metabolite perspective: a systematic review. Cancer Manag Res. 2018;31:199-206.

3. Aran V, Victorino AP, Thuler LC, Ferreira CG. Colorectal cancer: Epidemiology, disease mechanisms and interventions to reduce onset and mortality. Clin Colorectal Cancer. 2016;15:195-203.

4. Weinberg BA, Marshall JL. Colon cancer in young adults: Trends and their implications. Curr Oncol Rep. 2019;21:3.

5. Tse JW, Jenkins LJ, Chionh F, Mariadason JM. Aberrant DNA methylation in colorectal cancer: What should we target? Trends Cancer. 2017;3:698-712.

6. Xicola RM, Llor X. DNA methylation defects in sporadic and hereditary colorectal cancer. Gastroenterol Hepatol. 2012;35:480-7.

7. Kašubová I, Kalman $M$, Jašek K, Burjanivová $T$, Malicherová $B$, Vaňochová $A$, et al. Stratification of patients with colorectal cancer without the recorded family history. Oncol Lett. 2019;17:3649-56.

8. Sacho EJ, Kadyrov FA, Modrich PTA, Erie DA. Direct visualization of asymmetric adenine nucleotide-induced conformational changes in MutLa. Mol Cel. 2008;29:1-20.
9. Kobayashi H, Ohno S, Sasaki Y, Matsuura M. Hereditary breast and ovarian cancer susceptibility genes. Oncol Rep. 2013;30:1019-29.

10. Baert-Desurmont S, Buisine MP, Bessenay E, Frerot S, Lovecchio T, Martin C, et al. Partial duplications of the MSH2 and MLH1 genes in hereditary nonpolyposis colorectal cancer. Eur J Hum Genet. 2007;15:383-6.

11. Ito $E$, Yanagisawa $Y$, Iwahashi $Y$, Suzuki $Y$, Nagasaki $H$, Akiyama $Y$, et al. A core promoter and a frequent single-nucleotide polymorphism of the mismatch repair gene hMLH1. Biochem Biophys Res Commun. 1999;256:488-94.

12. Kent WJ, Sugnet CW, Furey TS, Roskin KM, Pringle TH, Zahler AM, et al. The human genome browser at UCSC. Genome Res. 2002:12:9961006.

13. Deng G, Chen A, Hong J, Chae HS, Kim YS. Methylation of CpG in a small region of the hMLH1 promoter invariably correlates with the absence of gene expression. Cancer Res. 1999;59:2029-33.

14. Deng G, Chen A, Pong E, Kim YS. Methylation in hMLH1 promoter interferes with its binding to transcription factor CBF and inhibits gene expression. Oncogene. 2001;20:7120-7.

15. Miyakura Y, Sugano K, Konishi F, Ichikawa A, Maekawa M, Shitoh K, et al. Extensive methylation of hMLH1 promoter region predominates in proximal colon cancer with microsatellite instability. Gastroenterology. 2001;121:1300-9.

16. Wong JJ, Hawkins NJ, Ward RL, Hitchins MP. Methylation of the 3p22 region encompassing $\mathrm{MLH} 1$ is representative of the $\mathrm{CpG}$ island methylator phenotype in colorectal cancer. Mod Pathol. 2011;24:396-411.

17. Hokazono K, Ueki T, Nagayoshi K, Nishioka Y, Hatae T, Koga Y, et al. A CpG island methylator phenotype of colorectal cancer that is contiguous with conventional adenomas, but not serrated polyps. Oncol Lett. 2014;8:1937-44.

18. Miyakura Y, Tahara M, Lefor AT, Yasuda Y, Sugano K. Haplotype defined by the MLH1-93G/A polymorphism is associated with MLH1 promoter hypermethylation in sporadic colorectal cancers. BMC Res Notes. 2014;7:1-11.

19. Wang Y, Li D, Li X, Teng C, Zhu L, Cui B, et al. Prognostic significance of $h M L H 1 / h M S H 2$ gene mutations and $h M L H 1$ promoter methylation in sporadic colorectal cancer. Med Oncol. 2014;31:1-8.

20. Veganzones S, Maestro ML, Rafael S, de la Orden V, Vidaurreta M, Mediero B, et al. Combined methylation of p16 and hMLH1 (CMETH2) discriminates a subpopulation with better prognosis in colorectal cancer patients with microsatellite instability tumors. Tumor Biol. 2015;36:3853-61.

21. Lee JA, Park HE, Yoo SY, Matsuura M. CpG island methylation in sessile serrated adenoma/polyp of the colorectum: Implications for differential diagnosis of molecularly high-risk lesions among non-dysplastic sessile serrated adenomas/polyps. J Pathol Transl Med. 2019;53:225-35.

22. Van IJ, Niessen HE, Derks S, Baldewijns MM, van Criekinge W, Herman JG, et al. Analysis of promoter $\mathrm{CpG}$ island hypermethylation in cancer. Location, location, and location! Clin Cancer Res. 2011;17:4225-31.

23. Li X, Yao X, Wang Y, Hu F, Wang F, Jiang L, et al. MLH1 promoter methylation frequency in colorectal cancer patients and related clinicopathological and molecular features. PLoS One. 2013;8:e59064.

24. Jones MJ, Goodman SJ, Kobor MS. DNA methylation and healthy human aging. Aging Cell. 2015;14:924-32.

25. Derry MM, Raina KC, Agarwal R. Identifying molecular targets of lifestyle modifications in colon cancer prevention. Front Oncol. 2013;3:1-20.

26. Jung SE, Shin KJ, Lee HY. DNA methylation-based age prediction from various tissues and body fluids. BMB Rep. 2017;50:546-53.

27. Hadjipetrou A, Anyfantakis D, Galanakis CG, Kastanakis M, Kastanakis S. Colorectal cancer, screening and primary care: A mini literature review. World J Gastroenterol. 2017;23:6049-58.

28. Dolatkhah R, Somi MH, Shabanloei R, Farassati F, Fakhari A, Dastgiri S. Main risk factors association with proto-oncogene mutations in colorectal cancer. Asian Pac J Cancer Prev. 2018:19:2183-90.

29. Levine AJ, Phipps AI, Baron JA, Buchanan DD, Ahnen DJ, Cohen SA, et al. Clinicopathologic risk factor distributions for MLH1 promoter region methylation in CIMP-positive tumors. Cancer Epidemiol Biomarkers Prev. 2016;25:68-75.

30. Varela-Rey M, Woodhoo A, Martinez-Chantar ML, Mato JM, Lu SC. AIcohol, DNA methylation, and cancer. Alcohol Res. 2013;35:25-35.

31. Jin F, Thaiparambil J, Donepudi SR, Vantaku V, Piyarathna DWB, Maity S, et al. Tobacco-specific carcinogens induce hypermethylation, DNA adducts, and DNA damage in bladder cancer. Cancer Prev Res (Phila). 2017:10:588-97.

32. Parrillo L, Spinelli R, Nicolò A, Longo M, Mirra P, Raciti GA, et al. Nutritional factors, DNA methylation, and risk of type 2 diabetes and obesity: Perspectives and challenges. Int J Mol Sci. 2019;20:2983.

33. Noreen F, Röösli M, Gaj P, Pietrzak J, Weis S, Urfer P, et al. Modulation of age- and cancer-associated DNA methylation change in the healthy colon by aspirin and lifestyle. J Natl Cancer Inst. 2014;106:dju161. 